\title{
Harnâme’nin yapı unsurları ve muhteva bakımından incelenmesi
}

\section{İsa IŞIK'}

APA: Işık, İ. (2019). Harnâme'nin yapı unsurları ve muhteva bakımından incelenmesi. RumeliDE Dil ve Edebiyat Araşturmaları Dergisi, (16), 460-479. DOI: 10.2900o/rumelide.619017

\section{$\ddot{\mathbf{O z}}$}

Harnâme, mizah ve hiciv edebiyatı açısından önemli bir eserdir. 15. yüzyılda yazılmasına rağmen eserin şöhreti günümüze kadar ulaşmıştır. Harnâme'nin beğenilmesinin en önemli sebeplerinden biri işlenilen konunun güncelliğini koruyabilmesidir. Hikâyenin başarısında şairin rolü de unutulmamalıdır. Eser hacim olarak diğer mesnevilere nazaran küçük olmasına rağmen klasik bir mesnevide bulunması gereken bölümleri ihtiva etmektedir. Alegorik bir eser olan Harnâme'nin "Münâsebet-i Hikâyet” başlıklı asıl hikâye bölümünde bir eşeğin başından geçen olaylar anlatılır. Sahibi tarafından zor işlerde çalıştırılan zayıf ve cllız bir eşek, kendisini semiz öküzlerle karşlaştırarak boynuz sevdasına tutulur. Mesnevide boynuz sahibi olmak isteyen bir eşeğin kulağından ve kuyruğundan olması hikâye edilir. Hikâye üzerinden hırslı olmanın zararları dile getirilirken insanın elindekilerin kıymetini bilmesi gerektiğine dair mesajlar verilir. Bu makalede, Harnâme yapı unsurları ve muhteva bakımından incelemeye tabi tutulmuştur. Mesnevi, modern roman ve hikâye inceleme tekniklerinden istifade edilerek incelenmiştir. Anlatı; olay örgüsü, tematik ve biçimsel yapı, zaman, mekân, şahıs kadrosu, bakış açısı ve anlatıcı, anlatım teknikleri, dil ve üslup başlıkları altında ele alınmıştır. Harnâme üzerinde inceleme yapılırken yapı unsurlarının ve muhtevasının eserin başarısına katkıları değerlendirilmiş ve tartışılmıştır.

Anahtar kelimeler: Şeyhî, mesnevi, Harnâme, yapı unsurları, muhteva.

\section{Analysis of Harnâme in terms of structural elements and content}

\begin{abstract}
Harnâme is an important work in terms of humour and satire literature. Although it was written in the 15th century, the work's fame has survived to the present day. One of the most important reasons for the appreciation of Harnâme is that it addresses every period. The role of the poet in the success of the story should not be forgotten. Although the work is small compared to other mesnevis in volume, it contains the parts that should be found in a classical mesnevi. In Harnâme, which is an allegorical work, the events that happen to a donkey are told in the main story section titled "Münâsebet-i Hikâyet". A weak and rickety donkey, employed by the owner in hard work, is infatuated with horns by comparing itself to the fleshy oxen. In Mesnevi, the story of a donkey that wants to have a horn but loses its ear and tail is told. While the damages of being ambitious are expressed via the story, messages are given that one should know the value of his/ her possessions. In this article, Harnâme is examined in terms of structural elements and content. While examining mesnevi, modern novel and story analysis techniques were used. The narration are discussed under headings such as the plot, thematic and formal structure, time, space, individual staff, point of view and the narrator, narrative techniques, language and style. While examining Harnâme, the
\end{abstract}

1 Dr. Öğr. Üyesi, Muş Alparslan Üniversitesi, Fen Edebiyat Fakültesi, Türk Dili ve Edebiyatı Bölümü (Muş, Türkiye), i.isik@alparslan.edu.tr, ORCID ID: 0000-0003-0470-8180 [Makale kaylt tarihi: 21.08.2019-kabul tarihi:20.09.2019; DOI: $10.29000 /$ rumelide.619017] 
contribution of structural elements and content to the success of the work has been evaluated and discussed.

Keywords: Şeyhî, mesnevi, Harnâme, structural elements, content.

\section{Giriş}

Mesnevi nazım biçiminin her beytinin kendi içinde kafiyelenmesi bu tarzda eser veren şairlere büyük kolaylıklar sağlamakta ve bu nazım biçimiyle uzun uzadıya eserlerin yazılmasına imkân sunmaktadır. Mesneviler, klasik Türk edebiyatında yüzyllarca toplumun anlatı ihtiyacını gidermiştir. Klasik şiirin etkisinin azalması ve modernizmin Türk toplumuna tesiriyle beraber özellikle Tanzimat'tan sonra mesnevi nazım biçiminin yerini romanın aldığı görülmektedir. Bundan dolayı mesnevilerin romanın ilk şekli olduğunu iddia edenler olduğu gibi roman ve mesnevinin birbirinden bağımsız olduğunu iddia edenler de vardır. ${ }^{2}$ Mesneviler belli bir dönem toplumun anlatı ihtiyacını giderseler de romandan farklıdır. Mesnevilerde bulunan dibace, tevhid, na’t, medhiye, sebeb-i telif gibi bölümler modern romanlarda bulunmaz. Ayrıca mesnevinin aruz kalıbıyla ve manzum olarak yazılması da onu romandan/ hikâyeden ayıran önemli özelliklerdendir. Bunun yanında mesnevi ve roman/ hikâye; olay örgüsü, zaman, mekân ve şahıs kadrosu gibi benzer yapı unsurlarına sahiptir. "Mesnevilerde Türk romanını şekillendiren özellikleri ve hikâyeleme tekniklerini bulmak mümkündür” (Ece 2002: 99). Bu çalışmada 15. yüzyılda Şeyhî tarafından kaleme alınan Harnâme, yapı unsurları ve muhteva bakımından incelenmeye tabi tutulmuştur. Modern hikâye/roman incelemelerinin kullanıldığı bu çalışmada Harnâme'nin modern bir hikâye olduğu iddiasında olmadığımızı belirtmek isteriz. "Zira bu yaklaşım, türleri kendi tarihsel bağlamında konumlandırarak çözümlemeler yapmaya, yorumlamaya yöneliktir" (Kekeç 2017: 193).

Harnâme'nin mizah ve hiciv edebiyatımızın dönüm noktasında olması, tahkiyeli ve sade bir Türkçeyle yazılması, etkisinin günümüze kadar ulaşması gibi sebepler de göz önünde bulundurularak eserle ilgili farklı bakış açılarını ortaya çıkaracağı düşüncesinden hareketle böyle bir çalışma yapılmasına gerek duyulmuştur. ${ }^{3}$ Eserin inceleme safhasına geçmeden önce Harnâme'ye dair bazı bilgilerin verilmesi konunun daha iyi anlaşılması açısından faydalı olacaktır:

Gerçek adı Yusuf olan Şeyhî, Hekim Sinan adıyla tanınmış, hekimler arasında uzmanlığıyla bilinmiştir (İsen,1990: 444-445; Kutluk, 1997: 141). Harnâme, onun en çok bilinen eseridir. Harnâme'nin II. Murad'a ve I. Mehmed'e sunulduğuna dair rivayetler vardır. Mengi, eserin önce I. Mehmed'e sonra II. Murad'a sunulduğunu ifade eder (2012:119). Kınalızâde Hasan Çelebi ve Gelibolulu Ali Harnâme'nin Çelebi Mehmed'e sunulduğunu söyler (Kutluk, 1989: 529-530; İsen, 1994: 113-114). Heşt Bihişt’te, Hüsrev ü Şirin’i yazan Şeyhî’nin bol miktarda in'am ve ihsan gördüğ̈̈ belirtilir. Bu rivayete göre memleketine dönen Şeyhî yolda baskına uğrar. Her şeyini kaybeden Şeyhî’nin arz-ı hâl kâbilinden Harnâme'yi nazma çektiği ifade edilir (İsen, 1998:112). Çelebi Mehmed’in padişahın gözünü tedavi etmesinden dolayı Şeyhîye Tokuzlar Köyü’nün tımar olarak verildiği de rivayet edilir. Bu rivayete göre Şeyhî, Tokuzlar Köyü’ne giderken tımarın eski sahipleri tarafından dövülür. Şair, Harnâme’yi yazarak hâlini padişaha arz eder (Timurtaş 1971: 6).

Harnâme kendi içerisinde eleştiri barındıran satirik bir eserdir. "Hayvanların ağzından insanın dünyasına ayna tutan şair, hayal ile gerçeği yüzleştirmiş; mizah ile şiiri, övgü ile yergiyi sembolik bir

Benzer çalışmalardan bazıları için bkz. Demirel 2001, Ülger 2003, Özger 2004, Köksal 2005, Alemdaroğlu 2008, Aktaş 2011 
anlatımla karşı karşıya getirmiştir" (Özdemir 2010: 70). "Şeyhî, Harnâme’de başvurduğu satirik bakış açısıyla Türk şiirine felsefi derinlik getirmiştir. Teşhis ve intak yoluyla, hayvanların dilinden insanların dünyasına eğilerek ince bir mizahla insanî zaafları hicvetmiş, aynı zamanda sanat vasıtasıyla toplumsal eleştiri de yapmıştır" (Özdemir 2010: 79).

Şeyhî hikâyesinin konusunu, Emir Hüseynî’nin Zadü’l-müsâfirin adlı eserindeki küçük bir eşek hikâyesinden almış olmalıdır. Ancak Şeyhî’nin bu eserini Firdevsî’nin Şeh-nâme'sinden ve Fahrî’nin Hüsrev ü Şîrîn'inden ilham alarak yazmış olması da ihtimal dâhilindedir. Kelile ve Dimne'de kuyruğu olmayan bir eşeğin kuyruk ararken kulağından olmasını anlatan hikâyenin de esere ilham kaynağı oluşturması yine ihtimal dâhilindedir (Şentürk ve Kartal 2009: 218-219). Eser, mizah ve hiciv edebiyatının ilk ve önde gelen eserlerinden olup sade bir Türkçeyle yazılmıştır. Eserde Arapça ve Farsça kökenli kelime ve tamlamalar kullanılmasının yanında bazı beyitlerin tamamı öz Türkçe ile kaleme alınmıştır (Şentürk ve Kartal 2009: 219).

Harnâme, 126 beyitten oluşan kısa bir mesnevidir. Bir mesnevide bulunması gereken tevhid, na’t, padişah medhiyesi, sebeb-i telif, asıl hikâye, dua gibi bölümleri muhtevidir. Eser, büyük bir mesnevinin bütün bölümlerinin belli ölçülerle küçültülmüş bir örneği gibidir (Timurtaş 1971: 9-13). Bu makalenin asıl çalışma alanı eserin "Münâsebet-i Hikâyet” bölümüdür. Asıl hikâye bölümü olan bu kısım modern roman/öykü tahlili yöntemlerinden istifade edilerek yapı unsurları ve muhteva bakımından incelemeye tabi tutulmuş, bu bağlamda eserin kıymeti tartışılmıştır.

\section{Olay örgüsü}

Yük çekmekten perişan olmuş bazen odunda bazen suda çalışan bir eşek vardır. Sırtında yaralar oluşmuş, çektiği ağır yüklerden, yediği dayaklardan dolayı bir deri bir kemik kalmıştır. Bu hayvan bir gün sahibi tarafından salıverilir. Dışarıda dolaşan eşek tarlada öküzleri görür. Öküzlerin semirmiş olması ve güzel boynuzlara sahip olması onun öküzlere öykünmesine sebep olur. Eşek; şekil ve surette kendilerine benzeyen öküzlerin niçin bu kadar refah içerisinde olduklarını sorgular. Bu durumu anlamlandırmak için eşeklerin pirine gider. "Akıllı eşek" öküzlerin rızkın ortaya çıkmasına sebep oldukları için, boynuza layı olduklarını; eşeklerin işininse odun taşımak olduğundan kuyruk ve kulağın bile onlara fazla olduğunu söyler. Akıllı ve pir eşekten istediği cevabı alamayan "akılsız eşek" pir eşeğin yanından ayrıldıktan sonra kendisinin de öküzler gibi arpa buğday işleyeceği ve dişleyeceği kararını alır. Karnı aç olan hayvan yemyeşil, göğermiş bir tarlaya dalar. Ne gördüyse yer, yemyeşil tarlada üründen eser kalmaz. Karnını doyurduktan sonra türküler tutturur. Onun anırıp bağırması tarla sahibinin kulağına gider. Tarla sahibi, eşeğe küfürler savurur. Onu döver, bununla da yetinmeyip boynuz sahibi olmak için yola çıkan eşeğin kulağını ve kuyruğunu keser. Gözyaşı yerine kanı dökülerek can havliyle koşan hayvan, pir eşeğe rastlar. Başından geçenleri "boynuz umarken, kulaktan ayrıldım” şeklinde kısaca özetler.

Hikâye hareketlidir, hikâyede olaylar zinciri mevcuttur. Esere "olay hikâyesi" diyebiliriz. Eserde tasvirlere de yer verilmesine rağmen sürekli bir hareket ve değişim görülür. Eserde bazı olaylar tamamıyla kırılma noktası hüviyetine bürünür. Mesnevide, kırılma noktası diyebileceğimiz olaylar şöyle siralanabilir:

1.Eşeğin sahibi tarafından otlağa salınması,

2.Eşeğin öküzleri görüp onlara hayran kalışı,

3.Başkahraman olan eşeğin pir eşeğe gidip hâlini arz etmesi, 
4.Eşeğin hırsla tarlaya dalışı,

5.Eşeğin karnını doyurduktan sonra türküler tutturması (bağırıp çağırması, anırması),

6.Tarlanın sahibinin eşeğin sesini duyması ve sonrasında kulağını ve kuyruğunu kesmesi.

\section{Tematik yapı}

“Şeyhî’nin içtimai eşitlik fikrini işleyen, herkes yaptığı işin değeri kadar refaha layıktır, şeklinde bir içtimai adalet görüşü ileri süren ve meseleyi neticede kadere bağlayan, düzene aykırı hareket edenlerin ceza göreceklerini belirten bu küçük mesnevisi, edebî bakımdan büyük değer taşımaktadır" (Timurtaş, 1971: 13).

A.Yekta Saraç 'Divan Edebiyatında Hikâye' başlıklı yazısında hikâyeleri konularının niteliklerine göre beşe ayırır. Bunlar: "1.Dinî konulu hikâyeler. 2.Aşk hikâyeleri. 3.Tarihî ve efsanevi şahısları konu alan hikâyeler. 4.Temsilî- alegorik hikâyeler. 5.Tasavvufi hikâyeler.” olarak beşe ayırır (Saraç, 2000: 123) Bu bağlamda Harnâme temsilî- alegorik bir hikâyedir.

Elindekilerin kıymetini bilmeyen, daima fazlasını arzulayan haris insanların başına gelebilecekleri konu edinen eser, yazılmasından bugüne kadar uzun süre geçmesine rağmen ilettiği ana fikir bakımından tazeliğini korumaktadır. Aşağıdaki ifade şairin sunmak istediği iletiyi özetler niteliktedir:

Batıl isteyü Hak'dan ayrıldım

Boynuz umdum kulakdan ayrıldım (112)4

\section{Biçimsel yapı}

Şeyhî’nin eseri, olay anlatımı esasına dayalı vezinli, kafiyeli bir mesnevidir (Doğan, 200o: 133). Feilâtün/ mefâilün/ feilün kalıbıyla kaleme alınmıştır. 126 beyitten oluşan eser, kısa bir mesnevi olmasına rağmen sunmak istediği mesaj ve iletiler bakımından başarılıdır. Harname'nin ilk 7 beyti tevhid bölümüdür. Sonraki 5 beyit na'ttır. Harnâme'nin na't bölümünden sonra 26 beyitlik "Dua-yı Devlet-i Şâh” bölümü gelir. Bu bölümün ilk 22 beytinde padişaha övgüde bulunulur. Mezkûr bölümün son dört beytinde şair, padişahın devrindeki her şeyin olumlu gitmesine rağmen kendi bahtsızlığından yakınır. Sonraki bölüm, "Münâsebet-i Hikâyet” başlığını taşıyan asıl hikâyenin anlatıldığı bölümdür. Bu bölümün akabinde dua bölümü gelir. Şeyhî, eserini umumiyetle insan dışı varlıklar üzerine kurgulamıştır.

Şair, padişaha övgü bölümünden sonra kaleme aldığı dört beyitte kendi bahtsızlığından yakınarak eserin telif sebebini şu mısralarla açıllar:

Zevk içinde cihân velî Şeyhî

Yatur uş mihnet ü belâda dahı

Bahtı zengi yüzi tek ağarmaz

İşi basmaklayın başa varmaz

4 Bu çalı̧̧mada Timurtaş'ın yayımladığı Harnâme metninden (Timurtaş: 1971) istifade edilmiştir. Parantez içindeki rakamlar, bahsi geçen çalışmadaki eserin beyit numaralarını göstermektedir. 
Râhat umdukça gördi zahmetler

Devlet isteyü buldı mihnetler

Fikr olurken bu hâletün sıfatı

Geldi bu kıssanın münâsebeti (35-38)

\section{Harnâme'de zaman}

Harnâme, 15. yüzyılda kaleme alınan bir metindir. Bu eserde şairin başından geçen olaylar alegorik bir tarzda anlatılmıştır. Eser, verdiği mesajlarla günümüz insanına da hitap etmektedir. Eserin konusu her dönem insanına hitap ettiği için hikâye, yüzyıllar geçse de etkisini devam ettirmektedir.

Harnâme mesnevisinin başlangıç zamanı, zayıf olan eşeğin tasviriyle başlar. Eşeği fiziki özellikleriyle tanıtan şair, eşeğin ahvâlinin sebebini izah ederken zamanın onu eskitip güçsüz düşürdüğünden söz eder. Hikâye eşeğin tasviriyle başlarken kullanılan zaman kipi görülen geçmiş zamandır.

Aşağıdaki mısralarda şair her ne kadar görülen geçmiş zaman kipini kullansa da buralarda kullanılan zaman ifadeleri kesin bir zamanı ifade etmez. Bu ifadeler eşeğin neredeyse bütün zamanlarda zorluk içerisinde bir hayat geçirdiğini dikkatlere sunar:

Bir eşer var idi zâif ü nizâr

Yük elinde katı şikeste vü zâr

Gâh odunda vü gâh suda idi

Dün ü gün kahr ile kısuda idi (39-40)

Eşeğin gâh odunda gâh suda olması onun yaptığı eylemleri gösterdiği gibi ikinci mısrada geçen "dün ü gün” kahr ile kısuda olması bu eylemin genellikle tekrar eden bir eylem olduğunu nazarlara sunar. Eşeğin neredeyse bütün zamanlarda sıkıntı içerisinde olması onun trajik-komik sonunu hazırlar. Çalışmaktan zayıflayıp perişan hâle gelen eşek "bir gün" sahibi tarafından ota salınır. Şairin bahsini ettiği "bir gün" herhangi bir gündür. Bahsi geçen günün tarihi kesin olarak belli değildir. Nitekim Harnâme’de geçen zamanlar, genel olarak kesin zaman ifadesi taşımaz:

Bir gün ıssı ider himâyet ana

Ya'ni kim gösterür inâyet ana (48)

Sahibi tarafından dışarıya salınan eşek öyle bir zaman ve mekânla karşılaşır ki bu, onun bütün geçmişini hatta fitratını sorgulamasına kadar gider. Eşek, öküzlerin otlaktaki hâllerini görünce kendisini ve eylemlerini sorgular. Öküzlerin başındaki ay ve yay gibi duran boynuzlar, eşeğin zihninde öküzlere karşı bir öykünmeye sebep olur. Eşek, gördükleri karşısında kendisiyle öküzleri karşılaştırma firsatı bulur. Eşekler zamanlarını odun ve su taşımakla geçirirken öküzlerin zamanları yemek içmekle ve keyifle geçmektedir. Öküzler, kimi zaman gönülleri hoş bir şekilde yürürken kimi zaman da kışlalarda ve yaylalarda gezinir:

Geh yürürler ferâgat ü hoş-dil

Gâh yaylâ vü kışla geh menzil (55) 
Harnâme'de zaman kronolojik olarak ilerler. Sadece akıllı eşeğin bilgeliğini anlatmak için geriye dönüş tekniği kullanılarak geçmiş zamanlardan bahsedilir. Akıllı eşek, görmüş geçirmiş biridir:

Var idi bir eşek firâsetlü

Hem ulu yollu hem kiyâsetlü

Çok geçürmiş zamâneden çağlar

Yükler altında sızırup yağlar

Nûh Peygamberün gemisine ol

Virmiş İblîse kuyruğıyla yol

Dir imiş ben döşedidüm döşeği

Dirilürken ölüp ‘Üzeyr eşeği

Hoş-nefesdür diyü vü ehl ü fasîh

Hürmet eyler imiş hımâr-ı Mesîh (62-66)

Şair, hikâyede olay örgüsünü keserek geçmişe dönüş yapar ve akıllı eşekten söz eder. Şeyhî, onun yaşamını Nûh Peygamber'in zamanına kadar götürür. Nûh Tufanı'na telmih yapan şair, akıllı eşeğin aklıyla şeytana bile rehberlik yaptığı mesajını verir. Şeyhî, akıllı eşeğin Nuh Tufanı esnasında şeytana gemiye geçmesi için kuyruğuyla yol verdiğini söyler. Şair, Hazreti Üzeyr’in eşeğinin dirilirken döşeğini döşeyenin akıllı eşek olduğunu da ifade eder. Bu eşek öyle itibar ehli birisi olarak gösterilmiştir ki Hazreti İsa'nın merkebinin bile buna hürmet ettiği söylenir.

Öküzlerin başındaki boynuza öykünen akılsız eşek, akıllı eşeğe danışır. Fakat akılsız eşek, akıllı eşeğin kendisine verdiği tavsiyeleri dinlemez. Huzurdan ayrılınca gördüğü yemyeşil tarlaya dalar. Tarlayı talan eder. Sonra kendince türkü söyleyen akılsız eşeğin sesi, tarlanın sahibine ulaştığı zaman işler kopma noktasına gelir. Boynuz uman eşek tarlanın sahibinin hışmına uğrar. Böylece, hikâye zamanının sonunda, akılsız eşek hem kulağından hem de kuyruğundan olur.

\section{Harnâme'de mekân}

Şeyhî, eşeği tasvir ederken onun güçsüz ve zayif olduğunu gözler önüne serer. Başkahraman olan eşeğin zayıf olduğu nazarlara sunulurken eşeğin kendisi bir mekân gibi tasvir edilir. Onun sırtı odun ve suyun taşınma mekânıdır. Zayıf ve cılız olan eşeğin sırtı yara bere içerisindedir. Eşeğin kemikleri dışarıdan sayılabilecek bir iskelet gibidir. Eşek, öyle yorgun ve mecalsizdir ki sırtında bir sineği taşıyacak hâli kalmamıştır. Öyle ki onun eşek olduğuna dair tek alâmetifarikası sırtındaki palanıdır. Şair, eşeğin palanı alındığında bir köpek gibi zayıf göründüğünü anlatır:

Arkasından alınsa pâlânı

Sanki it artuğıydı kalanı (47)

Şeyhî eşeğin kulağını ve gözünü de bir mekân olarak resmetmiştir. Zira kargalar derneği eşeğin kulağı etrafında, sinekler de gözünün yağında dolaşmaktadır. 
Kargalar dirneği kulağında
Sinegün seyri gözi yağında (46)

Kargalar ve sineklerle beraber resmedilen mekân, başkahraman eşeğin hâlinin ne kadar kötü olduğunu göstermek içindir. Hâsllı, eşek ölmek üzere olan bir varlık olarak nazarlara sunulurken karga ve sinekler eşeğin ölmesini bekleyen leş yiyiciler gibi tasvir edilmiştir.

Harnâme'de başkahramanın kendi içerisinde yaşadığı temel çatışmanın sebeplerinden biri de mekândır. Harnâme'nin başkahramanının temel sorunu bulunduğu yeri beğenmemekten kaynaklanır. $\mathrm{O}$, sahibinin elinde sürekli çalıştırılarak ve aç bırakılarak zulme uğramıştır. Nitekim hikâyenin temel dönüşümü eşeğin sahibinin, palanını çıkarıp onu ota salmasıyla vuku bulur. Eşek biraz öteye yürüyünce otlakta yürüyen öküzlerle karşılaşır. Öküzlerin dikkat çeken tarafı semirmiş olmaları ve otlak içerisinde dilediklerince hareket edip otlamalarıdır:

Gördi otlakda yürür öküzler

Odlu gözler ü gerlü gögüzler

Sömürüp eyle yirler otlağı

Ki çekicek kılın tamar yağı (50-51)

Öküzlerin tarlada otlamaları dikkat çekerken dikkati çeken bir diğer unsur da öküzlerin boynuzlarıdır. Öküzlerin rahat ve huzur içinde tarlada yiyip içmeleri, seslerinin gürlüğü, özgürlükleri, yayla ve kışlakları mekân tutmaları şairin başkahramanı olan eşeği cezbeder. Eşek, kendi sırtındaki palandan ve ağzındaki yulardan rahatsız olurken öküzlerin başındaki boynuz ona bir tac gibi görünür. Bu durum onu sorgulamaya götürür:

Bunlarun başlarına tâc neden

Bizde bu fakr u ihtiyâc neden (59)

Yukarıdaki ifadelerle özetlenerek yapılan sorgulama, eşeği, akıllı eşeğe yönlendirir. Akıllı eşek hikmetli, ferasetli olmasının yanında fiziki olarak da güçlü bir görünüme sahiptir. Akılsız eşeğin kulaklarının etrafında kargaların uçuştuğunu söyleyen şair, akıllı eşeğin kulaklarından kurtların korktuğunu beyan eder. Akıllı eşeğin bulunduğu mekâna gelen akılsız eşek, hâlini akıllı eşeğe arzeder; fakat müşkilini halledemez. Yoldan dönerken bir tarlayla karşılaşır. Bu tarla yemyeşil ve cezbedici bir mekândır. Eşek bu tarlaya girince kendi trajik sonunu hazırlar:

Gezerek gördi bir gögermiş ekin

Sanki dutardı ol ekin ile kîn

'Işk ile degdi girdi işlemege

Gâh ayaklayu gâh dişlemege

Arpa gördi gögermiş aç eşek

Buldı cân derdine ilâç eşek
Krrklareli University, Faculty of Arts and Sciences, Department of Turkish Language and Literature, Kayalı Campus-Kırklareli/TURKEY e-mail: editor@rumelide.com 
Degme kerret ki şevk ile karvar

Toprağın bile götürür harvâr

Eyle yidi gök ekini terle

Ki gören dir zihî kara tarla (93-97)

Eşeğin ilk gördüğü vakitte yemyeşil olan tarla, burada otlamasıyla kara bir tarlaya dönüşmüştür. Nitekim hikâyenin sonunda eşeğin hem kuyruğundan hem de kulağından olmasının sebebi tarlada sebep olduğu dönüşümdür. Zira şair, tarla sahibinin aklını başından götüren şeyin de tarlanın dönüşümü olduğunu beyan eder:

\author{
Ağaç elinde 'azm-i râh itdi \\ Tarlasını göricek âh itdi \\ Dâneden gördi yiri pâk olmış \\ Gök ekinligi kara hâk olmış \\ Yüregi sovumadı sögmeg ile \\ Ulımadı eşegi dögmeg ile \\ Bıçağın çekdi kodı ayruğını \\ Kesdi kulağını vü kuyruğını (105-108)
}

Şeyhî, başkahramanı olan eşeği mekânlar arasında gezdirirken tarla sahibinin eliyle cezalandırır. Eşek hırsının ve düşüncesizliğinin bir sonucu olarak kulağından ve kuyruğundan olurken aklı, elindekileri kaybettiğinde başına gelir. Fakat iş işten geçmiştir. O, boynuz umarken kulaktan da ayrılmıştır. Şeyhî eserinde mekân üzerinden bazı tahliller yaparken okuyucuya dünya malına karşı hırslı olunmaması, olaylar karşısında akılla hareket edilmesi ve her varlığın kendi ontolojik alanını bilmesi gerektiği mesajını da verir. Eşeğin trajik sonunu hazırlayan şey, eşeğin dar bir mekândan geniş bir mekâna açılmasıdır. Eşeğin sahibi, eşeği saldıktan sonra eşek bir nevi kral olmanın yolunu gözetmiştir. Eşeğin öküzlerin başındaki boynuza özenmesinin ve boynuzları taca benzetmesinin altında bu gibi sebepler yatmaktadır. Kendi varlığını öküzlerin varlığıyla bir görüp onlar gibi hareket eden eşek, yemyeşil bir tarlaya dalıp burayı alt üst edince şair tarafından tarla sahibinin eliyle cezalandırılır. Şeyhî, hikâyesine eşeği tasvir etmekle başlarken eşeğin önceki mekânı hakkında bilgi vermez. Fakat sonraki zamanlarda eşeğin gösterdiği tavırlardan dolayı yaşadığı mekânın berbat olduğunu söylemek mümkündür. Hatta berbat olan sadece onun yaşadığı mekân değil, her şeydir. Bunun baş müsebbibi de eşeğin sahibidir. Zira eşeğin sonraki zamanlarda yaptığı yanlışların temelinde hep eşek sahibinin eşeği bir şeylerden mahrum bırakması yatmaktadır. Eşeğin gördüğü mekânlara karşı hırslı olmasının ve boynuzlara öykünmesinin temel sebebi budur.

\title{
6.Şahıs kadrosu
}

Kurmaca eserlerde insanın yanında, insana dair özellikler gösteren varlık ve kavramlar da şahıs kadrosuna dâhil edilir. İnsan dışındaki mezkûr unsurlar metinde, şahıs karakteriyle ortaya çıktıkları gibi bunlarda şahıslandırmanın kazandırdığı vasıflar diğer özelliklerinin önünde gelir (Aktaş, 2005: 133- 
134). Şeyhî'nin Harname'si de şahıs kadrosu itibariyle genellikle insan dışı varlıklar üzerine inşa edilmiştir. Özellikle eserin ana kişileri insan dışı varlıklardır. Eserin "Münâsebet-i Hikâyet" bölümü başkahraman olan eşeğin fiziki özelliklerinin tasviriyle başlar. Bu eşek zaylf ve çelimsizdir. Yük taşımaktan hâli perişândır. Odun ve su taşıyan bu eşek daima kahır ve dert çekmektedir. Ağır yükler taşımaktan vücudu yara bere içerisinde kalmış, eti ve derisi yıpranmıştır:

Bir eşek var idi za‘îf ü nizâr

Yük elinden katı şikeste vü zâr

Gâh odunda vü gâh suda idi

Dün ü gün kahr ile kısuda idi

Ol kadar çeker idi yükler ağır

Ki teninde tü komamışdı yağır

Nice tü kalmamışdı et ü deri

Yükler altında kana batdı deri (39-42)

Eşeğin fiziki özelliklerindeki zayıflık onun fitrî özelliği olmayıp gece gündüz çalıştırılmasından ve ona yaptırılan işlerle adeta zulmedilmesindendir. Bahsi geçen eşeğin hâli iyi değildir. Öyle ki bütün kemikleri görülebilecek bir iskelet gibidir. Şair, eşeği görenlerin bu hâlinden dolayı hayret içerisinde kaldığını söyler. Şayet sırtından palanı alınınca geriye sanki it artığından kalma bir kemik yığını kalmaktadır:

Eydür idi gören bu sûretlü

Tan degül mi yürür sünük çatlu

Dudağı sarkmış u düşmiş enek

Yorılur arkasına konsa sinek (43-44)

$\cdots$

Kargalar dirneği kulağında

Sineğün seyri gözi yağında

Arkasından alınsa pâlânı

Sanki it artuğıydı kalanı (46-47)

Yukarıdaki beyitlerde Şeyhî’nin hikâyesinde bahsi geçen kargalar ve sinekler söz konusudur. Şair bunlardan ayrıntılı bir şekilde bahsetmez. Bunlar, eşeğin ölmesini bekleyen fon karakterler olarak nazarlara sunulur. Görüldüğü üzere başkahraman eşek, kötü bir hâldedir. Eşeğin fiziki hâli, başına gelecek belalarda önemli rol oynar. Eşeğin sahibi bir gün eşeğin palanını sırtından alıp ota salınca eşek için yeni bir dönem başlar. Öküzlerin görünüssleri karşısında hayretler içerisinde kalan akılsız eşek, kendi ahvaliyle öküzlerin halini sorgulama ve karşlaştırma fırsatı bulur. Eşeğin cılız yapısının karşısında öküzler kilolu, semirmiş, iri ve güçlü hayvanlardır. Bazı öküzlerin iri yapılarını süsleyen boynuzları, şair tarafından aya benzetilirken bazısı şekil olarak yaya benzetilir. Öküzlerin fiziki yapıları gibi sesleri de güçlüdür: 
Gördi otlakda yürür öküzler

Odlu gözler ü gerlü gögüzler

Sömürüp eyle yirler otlağı

Ki çekicek kılın tamar yağı

Boynuzı ba'zisınun ay bigi

Kiminün halka halka yay bigi

Böğrişüp çün virürler âvâze

Yankulanurdı tă̆ ü dervâze (50-53)

Şeyhî’nin Harnâme'sindeki eşek, öküzleri sadece dış görünüşleriyle değerlendirmez. Öküzleri seyreden eşek, birçok yönden onlara hayran kalır. Onun bu hayranlığı öküzlerle eşekler arasında bir mukayese yapılması şeklinde şairin mısralarına yansır. Öküzler, gönülleri rahat bir şekilde gezer. Bunlar bazen kışlaklarda bazen yaylaklarda gezinir. Eşek, öküzlerin bu hâllerini görünce onlara karşı kendisinde büyük bir hayranlık başlar. Fakat bu hayranlık zamanla eşeğin öküzlere ve onların hayatlarına öykünmesine sebep olur. Şeyhî’nin başkahramanı olan eşek yaptığı tefekkür ve tasavvurlarla eşeklerle öküzleri karşlaştırma firsatı bulur. El, ayak, şekil ve surette öküzlerle eşekler birbirlerine çok benzemelerine rağmen öküzlerin başındaki taç (boynuz) eşeğin aklını başından alır. Zira öküzlerde ne yular ne de palan derdi vardır. Onlar, eşekler gibi yük altında ezilmezler. Eşekler bir parça arpanın hayalini kurarken öküzler bu hayalin bizzat içerisinde yaşamaktadır:

Har-ı miskîn ider iken seyrân

Kaldı görüp sığırları hayrân

Geh yürürler ferâgat ü hoş-dil

Gâh yaylâ vü kışla geh menzil

Ne yular derdi ne gâm-ı pâlân

Ne yük altında haste vü nâlân

Acebe kalur u tefekkür ider

Kendü ahvâlini tasavvur ider

Ki birüz bunlarunla hilkatde

Elde ayakda şekl ü sûretde

Bunlarun başlarına tâc neden

Bizde bu fakr ü ihtiyâc neden

Bizi gör arpa okı yây itdi

Bunlarun boynuzın kim ay itdi (55-60) 
Öküzlerin aşırı rahatlık ve bolluk içerisinde olmaları eşeğin bu mesele üzerinde kafa yormasına sebep olur. Bu hâlle ilgili zihninde birçok soru oluşan eşek, sorularına cevap bulmak için akıllı bir eşeğin kapısını çalar. Bu eşek, şairin başkahramanı olan eşekten farklıdır. Akıllı bir eşektir. Karşılaştığı durumlar karşısında ferasetli olan bu hayvan, olaylara ve nesnelere yüzeysel bakmaz. O, hikmet ehlidir. Şeyhî, onu görmüş geçirmiş birisi olarak nazarlara sunar. Öyle ki şair, bu eşeğin, Hazreti Nuh’un gemisinde şeytana kuyruğuyla yol verdiğini söyler. Bu eşeğin maharetleri bununla sınırlı değildir. $O$, Hazreti Üzeyr'in eşeği dirilirken döşeğini kendisinin döşediğini söyleyen biridir. Bu eşek güzel bir hitabete sahip olduğu için Hazreti İsa’nın eşeği bile ona hürmet eylermiş. Şair, bu eşeği zihnî yapısıyla akıllı ve mükemmel bir eşek olarak aktarır. Akıllı eşek, fiziki yapısıyla da cılız ve zayıf olan akılsız eşekten iri ve güçlü olarak tasvir edilir. (61-67)

Hâlini arz etmek için akıllı eşeğin huzuruna çıkan akılsız eşeğin aşağıdaki ifadeleri şairin akıllı eşeğe dair kanaatlerini özetler mahiyettedir:

Sen eşekler içinde kâmilsin

Âkıl ü şeyh ü ehl ü fâzlsın

Anda k'islâh ide tapun şer ü şûr

Har-î Deccâle diyeler ker ü kûr

Menzil-i mü'mînîne rehbersin

Merkeb-i sâlihîne mazharsın

Nesebündür mesel hatîblere

Nefesün hoş gelür edîblere (69-72)

Huzura varan eşek, kafasını karıştıran meseleyi akıllı eşeğe açar. Otlakta gördüğü öküzleri anlatan eşek, öküzlerin fiziki hâllerini tasvir eder. Bunlar semiz, kuvvetli, içi ve dışı yağlı öküzlerdir. Ayrıca bunların başlarındaki tacın mahiyeti de akılsız eşeğin kafasını karıştıran hususiyetlerdendir. Akılsız eşeğin ağzından aktarılan aşağıdaki mısralar, öküzlerin fiziki görünüşlerini nazarlara sunduğu gibi akılsız eşeğin nasıl bir sorgulama içerisine girdiğini de göstermektedir:

Bugün otlakda gördüm öküzler

Gerüben yürür idi gögüzler

Her birisi semîz ü kuvvetlü

İçi vü taşı yağlu vü etlü

Niçün oldu bulara erzâni

Bize bildür şu tâc-ı sultanî

Yok mıdur gökde bizüm ılduzumuz

K'olmadı yir yüzinde boynuzumuz (74-77) 
Yukarıdaki mısralardan da anlaşıldığı üzere akılsız eşekte bir boynuz sevdası başlamıştır. Eşeklerin boynuza layık olduklarını düşünen akılsız eşek bu durumu ve gördüklerini akıllı eşeğe arz eder. Akıllı eşek, akılsız eşeği dinledikten sonra ona nasihatte bulunur ve onu uyarır. Akıllı eşek, öküzlerin boynuz sahibi olmasını onların rızık sebebi olmasına bağlar. Akıllı eşeğe göre öküzler, gece gündüz arpa ve buğdayın yetişmesi için çaba harcayıp ekmeğin ortaya çımmasına sebep oldukları için bunlardan yerler. Bunların başlarındaki tacın da içlerindeki etin ve yağın da sebebi budur. Akıllı eşek, eşeklerin ise odun taşıdıklarını bundan dolayı boynuzun değil, kulak ve kuyruğun bile eşekler için fazla olduğunu söyleyerek akılsız eşeği uyarır. Akıllı eşekten istediği cevapları alamayan akılsız eşek yine kafasına göre hareket eder. Huzurdan ayrılan akılsız eşek yapılan izahlarla ikna olmaz. Buğday işlemekle öküz gibi olabileceğini düşünen eşek yemyeşil bir ekin tarlasına dalar. Bu tarlanın altını üstüne getirerek bu tarladaki yeşillikleri yer, yemyeşil tarlayı simsiyah kara bir tarlaya çevirir. Karnı doyunca keyiften anırmaya başlayan eşek, eşek sesinin dünyanın en kötü ve çirkin sesi olduğunu da bilmez. Onun anırması, trajik sonunu hazırlar. Eşeğin sesi tarlanın sahibine ulaşınca tarla sahibi yola koyulur. Tarlasının hâlini gören adamın aklı başından gider. Gördüğü manzara karşısında aşırı tepki verir. Eşeği döver. İçi soğumayınca da bıçağını çıkarıp eşeğin kulağını ve kuyruğunu keser. Can havliyle koşarak oradan uzaklaşan eşek yolda akıllı eşekle karşılaşır. Akıllı eşek onun ahvâlini sorunca akılsız eşek olayı şu sözlerle özetler:

Bâtll isteyü haktan ayrıldum

Boynuz umdum kulakdan ayrildum (102)

Akıllı eşek, şairin norm karakteridir. Norm karakterler, başkahraman ile fon karakter arasında bulunup bazen iki karakterin de belli vasıflarını kendilerinde bulundururlar. Bunlar, eserde başkahraman gibi etkili olmasa da onun eksikliklerini kapatan başkahramanın dünyasını aydınlatan bir özelliğe sahiptir (Demirel, 1995: 39; 2001: 196). Nitekim akıllı eşeğin nasihatleri hep akılsız eşeğin açıklarını kapatmak içindir. Ne var ki akılsız eşek bunlardan istifade etmez. Akılsız eşek, başına gelen musibetten sonra akıllı bir söylemde bulunmuştur. Fakat iş işten geçmiştir. Boynuz isteyen eşek kulaktan da kuyruktan da olmuştur. Eşeğin hırsı onun trajik bir son yaşamasına sebep olurken cezası tarlanın sahibinin eliyle verilir. Hikâyenin insan karakteri olan eşeğin ve tarlanın sahibi birbirlerine benzerler. Eşeğin sahibi eşeği zor işlerde çalıştırarak ona iyi bakmayıp zulmederken tarla sahibi de eşeği dövdükten sonra kulağını ve kuyruğunu keserek eşeği cezalandırmıştır.

\section{Bakış açısı ve anlatıcı}

Anlatıcının bakış açısı hikâyede, olayları, kişileri, zaman, mekân ve anlatının dilini etkiler. Anlatıcı eserini kurgularken roman/ hikâyenin unsurları üzerinde etkilidir. Sanatçı burada istediği tasarrufu yapar. Olayları istediği şekilde yönlendirir.

Harnâme'de "Hâkim Bakış Açısı" söz konusudur. Anlatıcı 3. şahıs anlatıcıdır. "O anlatıcı" hikâyeyi kurar, kahramanları yönlendirir, onların iç dünyalarında geçenleri bilir.

"O anlatıcı", yazarlar tarafından en fazla tutulan anlatıcıdır. Gücü ve yeteneğiyle anlatıyı yönlendirir. Onun kabiliyetiyle devreye sokulabilen 3. tekil kişi yöntemi, yazar ve şairlere büyük firsatlar sunar. Yazar/ şair bu yöntemin imkânlarıyla derinlemesine tahliller yapabilir (Tekin, 2001: 28).

Harnâme yazarı, eserini anlatırken kahramanlarını yönlendirir. Hatta gelecekteki bazı olaylar hakkında öngörülerde bulunur. Mekân tasvirleri, üslubun inşası ve eserin diğer özellikleri üzerinde hâkim bakış açısı görülür. Harnâme'de kahraman anlatıcı yani ben anlatıcıya (1.şahıs) kısmî olarak yer verildiğini de 
söyleyebiliriz. Özellikle başkahraman olan eşekle pir eşeğin diyalogları esnasında yazar anlatıcı aradan çıkar. Anlatı birinci ağızdan sürdürülür.

\section{Anlatım teknikleri}

\subsection{Anlatma}

Eserin genelinde şairin anlatma tekniğini kullandığı görülür. Özellikle hâkim bakış açısı ve yazaranlatıcı eserlerde anlatma tekniğinden sıkça yararlanıldı̆̆ı gibi Harnâme'de de bu teknikten istifade edilmiştir.

\subsection{Tasvir}

Harnâme'de realist tasvirler ön plana çıkar. Şeyhî minyatürden ziyade üç boyutlu bir resim çizer gibidir. Kelimelerle çizilen bu resimdeki çizgiler oldukça belirgindir. Özellikle eşeğin fiziki özellikleri açık bir şekilde tasvir edilir. Şairin bu tasvirleri yaparken yer yer mübalağa sanatından da istifade ettiği görülür:

Ol kadar çeker idi yükler ağır

Ki teninde tü komamışdı yağır

Nice tü kalmamışdı et ü deri

Yükler altında kana batdı deri (41-42)

...

Dudağı sarkmış u düşmiş enek

Yorlur arkasına konsa sinek (44)

...

Arkasından alınsa pâlânı

Sanki it artuğıydı kalanı (47)

Yukardaki beyitlerde eşeğin dış görünümünün net çizgilerle tasviri görülmektedir. Hikâyede tarlada otlayan öküzler de net çizgilerle betimlenmiştir. Öküzlerin boynuzunun teşbih yoluyla tek beyitte yapılan tasviri de dikkatlerden kaçmaz:

Boynuzı bazısının ay bigi

Kiminin halka halka yay bigi $(52)$

Yine başkahramanın, eşeklerin pirine otlakta gördüklerini (öküzleri) anlatması da şairin realist tasvirine örnektir, bu tablo doğadan çekilen bir fotoğrafı andırır:

Bugün otlakda gördüm öküzler

Gerüben yürür idi gögüzler

Her birisi semîz ü kuvvetlü

İçi vü taşı yağlu vü etlü (74-75) 
Eşeğin tarladaki göğermiş ekinleri yedikten sonra ortaya çıkan görüntü güzel bir tabiat tasviridir. Tarla sahibinin tarlasının hâlini görüp şaşırması da realist izlerin yansımasıdır:

$$
\begin{aligned}
& \text { Eyle yidi gök ekini terle } \\
& \text { Ki gören dir idi zihî kara tarla (97) } \\
& \text {... } \\
& \text { Dâneden gördi yiri pâk olmış } \\
& \text { Gök ekinliği kara hâk olmış (106) }
\end{aligned}
$$

\subsection{Diyalog}

Harnâme'de kullanılan anlatım tekniklerinden biri de diyalogdur. Özellikle "pir eşek"le başkahraman olan eşeğin diyalog yöntemiyle konuşturulduğu görülmektedir. Aşağıdaki beyitler üçüncü şahıs anlatıcının anlatım işini kahramanlarına bıraktığının göstergesidir. Onlar diyalog yöntemiyle anlaşırlar:
Böyle virdi cevâb pir eşek
Ki'y belâ bendine esîr eşek
Bu işün aslına işit illet
Anla aklında yog ise klllet
Ki öküzi yaradıcak Hallâk
Sebeb-i rızk kıldı ol Rezzâk (81)

Eşeğin pir eşeğin huzuruna gelişi anlatıldıktan sonra diyaloğa nasıl başladığı da aşağıdaki beyitlerde görülmektedir:

$$
\text { Ol ulu katına bu miskîn har }
$$

Vardı yüz sürdi didi ey server

Sen eşekler içinde kâmilsin

Âkil ü şeyh ü ehl ü fâzlsıın (69)

\section{4. İç monolog}

Harnâme yazarının monolog yöntemini kullandığı da görülmektedir. Eşek kendi haliyle öküzlerin ahvalini tefekkür ve tasavvur ederken aslında kendi kendine iç âleminde iç monolog yöntemiyle konuşur:
Acebe kalur u tefekkür ider
Kendi ahvâlini tasavvur ider
Ki birüz bunlarınla hilkatde
Elde ayakda şekl ü sûretde 
Bunlarun başlarına tâc neden

Bizde bu fakr u ihtiyâc neden

Bizi gör arpa okı yay itdi

Bunlarun boynuzın kim ay itdi

Didi bu müşkilümi itmez hal

Meger ol bir falan har-1 a'kal (57-61)

\subsection{Geriye dönüş tekniği}

Şeyhî, akıllı eşeği tanıtırken geriye dönüş tekniğini kullanarak geçmiş zamanlardan bahseder. O, birçok zamanları idrak etmiş, akıllı, hikmet ehli, ferasetli olup aynı zamanda fasih konuşan biridir:

Var idi bir eşek firâsetlü

Hem ulu yollu hem kiyâsetlü

Çok geçürmiş zamâneden çağlar

Yükler altında sızırup yağlar

Nûh Peygamberün gemisine ol

Virmiş İblîse kuyruğıyla yol

Dir imiş ben döşedidüm döşeği

Dirilürken ölüp ‘Üzeyr eşeği

Hoş-nefesdür diyü vü ehl ü fasîh

Hürmet eyler imiş hımâr-ı Mesîh (62-66)

\section{6.özetleme}

Harnâme'de yukarıdaki beyitlerde de görüldüğü üzere (64-66) “akıllı eşeğin” maharetleri sayılırken bazı hadiselerden bahsedilmiştir. Fakat bu hadiseler ayrıntılı bir şekilde anlatılmamış, yazar tarafından telmih yapılarak özetlenmiştir.

Görüldüğü üzere Şeyhî, Harnâme'yi kurarken birden fazla anlatım tekniği kullanarak eserini tekdüzelikten kurtarmıştır. Kısa bir hikâye olduğu nazar-ı dikkate alındığında Harnâme'nin, anlatım tekniklerinin kullanması açısından zengin ve başarılı olduğu söylenebilir.

\section{Dil ve üslup}

Şeyhî, Harnâme'de Türkçeye hâkimdir. Onun hâkimiyeti sadece Türkçeyi değil, Arapça ve Farsçayı da kapsar. Harnâme'de çoğunlukla Farsça tamlamalar kullanılmasına rağmen (gam-ı pâlân, tâc-ı sultâni, sebeb-i rızk, azm-i râh gibi) Arapça tamlamaların kullanıldı̆̆ı da görülmektedir (fethü'l-bâb, enkerü’l- 
asvât gibi). Harname'nin tevhid, na't ve padişahı öven bölümlerinde daha çok yabancı kelimeler kullanılmışken asıl hikâye kısmında ise daha açık ve anlaşılır bir dil kullanıldığı görülmektedir.

Şeyhî, eserinin bazı beyitlerinde sanatsal bir kaygı gütmezken, kimi beyitlerinde edebî maharetini ortaya koymaya çalışmıştır. Bazı beyitlerde edebî sanatlardan istifade eden şair, çoğu zaman eserinde anlatmak istediği asıl olayın kompozisyon çizgisinde bir yol izlemiştir.

\subsection{Edebî sanatlar}

Harnâme mesnevisinden alınan aşağıdaki örnek beyitler, şairin dil ve üslup bakımından başarısını gösterirken edebî sanatları kullanmadaki maharetini de nazarlara sunmaktadır. Harnâme eserinde kahramanların umumiyetle insan dışı varlıklar olmasından dolayı pek çok beyitte teşhis yapıldığı görülmektedir. Bunlardan bazıları şunlardır:

Acebe kalur u tefekkür eder

Kendü ahvâlini tasavvur eder (57)

Har-ı miskîn ider iken seyrân

Kaldı görüp sığırları hayrân (54)

İnsan dışı varlıkları konuşturma sanatı olan intakın olduğu her yerde teşhisin olduğunu da unutmamak gerekir. Harnâme'de özellikle eşekle, akıllı eşek arasındaki diyaloglarda intak sanatından faydalanıldığı görülmektedir. Eserin, temsilî-alegorik hikâye olmasından dolayı birçok yerde "intak" sanatı kullanılmıştır:

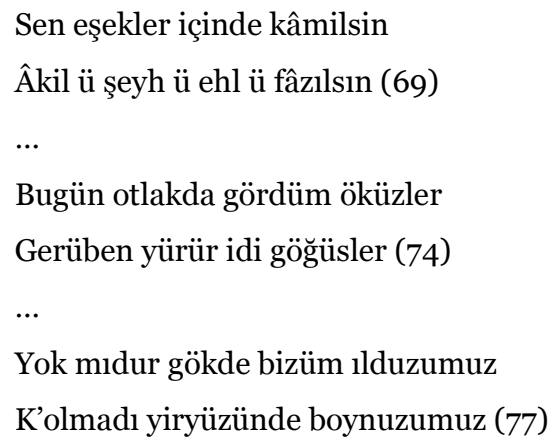

Aşağıdaki beytin ilk mısrasında öküzlerin boynuzu aya, ikincisinde halka halka yaya benzetilerek teşbih yapılmıştır:

Boynuzı bazısının ay bigi

Kiminün halka halka yay bigi (52)

Mesnevinin başka bir beytinde de yine öküzlerin boynuzu aya benzetilirken eşeklerin arpa hasretinden yay gibi büküldükleri ima edilir:

Bizi gör arpa okı yây itdi

Bunlarun boynuzın kim ay itdi (6o) 
Mesnevide "tâc" sözcüğü boynuza benzetilmiştir. Benzetme ögelerinden sadece birisi kullanılarak istiare sanatından faydalanılmıştır:

Bunlarun başlarına tâc neden

Bizde bu fakr u ihtiyâc neden (59)

Mizahî eserlerde, mübâlağanın dozu mizahî olmayan eserlere nazaran daha yüksektir ve bu durum mizahı ortaya çıkaran sebeplerdendir (Yılmaz, 2016: 203). Şair Harnâme’nin başkahramanı olan eşeği tanıtırken onun fiziki özelliklerini mübalağah bir dille anlatmıştır. Eşek, öyle perişan bir halde tasvir edilir ki eşeğin sırtına bir sinek konması bile onun yorulması için yeterlidir. Ayrıca eşek, o kadar zayıftır ki sırtından palanı alındığında sanki it artı̆̆ı gibi görülmektedir:

Dudağı sarkmış u düşmiş enek

Yorılur arkasina konsa sinek (44)

Arkasından alınsa pâlânı

Sanki it artuğıydı kalanı (47)

Şairin başkahraman eşeği tanıtırken kullandığı mübalağahı anlatım "akıllı eşeği” tanıtırken de devam eder:

Kurd korkar idi kulağından

Arslan ürker idi çomağından (67)

Harnâme'de akılsız eşek mübalağah bir şekilde zayıf bir karakter olarak çizilirken akıllı eşek ve öküzler bazı özellikleriyle yine abartılı olarak nazarlara sunulmuştur.

Eserin başkahramanı eşek, kafasındaki sorulara cevap bulmak için akıllı eşeğin kapısına gider. Aşağıdaki beyitte eşeğin intak sanatından da faydalanılarak nida yoluyla akıllı eşeğe hitap ettiği görülür.

Ol ulu katına bu miskîn har

Vardı yüz sürdi didi ey server (68)

Eşek, sahibi tarafından palanı alınıp otlağa salındıktan sonra öküzleri görünce kendi ahvaliyle onların halini karşılaştırır. Öküzlere niçin "tâc" şeklinde boynuz verildiği ve eşeklerin niçin bu kadar fakr u ihtiyaç içinde oldukları istifham yollu sorgulanır:

Bunların başlarına tâc neden

Bizde bu fakr u ihtiyâc neden (59)

Harnâme’nin başkahramanı olan eşek, öküzlerle kendi cinsi arasındaki farklılı̆̆ın sebebini öğrenmek için akıllı eşekle konuşurken irsal-i mesel nevinden aşağıdaki ifadeleri kullanır:

Her sığırdan eşek nite ola kem

Çün meseldür ki dir benî âdem

Har eger har ü bî-temîz oldı

Çünkü yük tartar ol azîz oldı (78-79) 
Harnâme'de, gördüğü tarlayı talan edip yiyen eşeğin yemekten sonra şarkı söylemesinin sebebi izah edilmektedir. Eşek, bunun sebebini bir irsal-i mesele dayandırır:

Dimiş ol âdemî ki hoş demdür

Ni'am oldukda bî-negam gamdur (100)

Hikâyede, "odun" ve "o dûn " kelimeleri arasında cinas yapılarak şiirde bir ahenk oluşturulmaya çalışılmıştır:

Bizüm ulu işümüz odundur

Od uran içümüze o dûndur (88)

Harnâme'de akıllı eşeğin, görmüş geçirmiş biri olduğundan bahsedilirken telmihe başvurulduğu görülür:

Nuh Peygamberün gemisine ol

Virmiş iblîse kuyruğıyla yol

Dir imiş ben döşedidüm döşeği

Dirilürken ölüp Üzeyr eşeği

Hoş nefesdür diyü ehl ü fasîh

Hürmet eyler imiş hımâr-ı Mesîh (64-66)

Görüldüğü üzere Şeyhî’nin Harnâme'si 126 beyitlik kısa bir mesnevi olmasına rağmen edebî sanatların kullanımı bakımından zengindir. Bütün bu tespitler ışığında şairin dil-üslup ve edebî sanatları kullanmada başarılı olduğu söylenebilir.

\section{Sonuç}

Harnâme, klasik tertibe uygun olarak yazılmış bir mesnevi olması bakımından modern anlatı türlerinden olan hikâye ve romandan farklıdır. Ancak eserin yapı unsurları, anlatı teknikleri ve muhteva yönü söz konusu türlerle benzer özellikler gösterir. Modern anlatı inceleme yöntemlerinin klasik bir esere uygulandığı bu çalışmada Harnâme; olay örgüsü, tematik ve biçimsel yapı, zaman, mekân, şahıs kadrosu, bakış açısı ve anlatıcı, anlatım teknikleri, dil ve üslup bakımlarından incelenmiştir. Buna göre;

Şeyhî, eserinde çizdiği tasvirlerde oldukça başarılıdır. Şair, anlatıda genellikle realist bir çizgide hareket ederken mübalağa sanatından da sık sık istifade eder. Şairin kahramanlarını fiziki ve fikrî boyutlarıyla anlatırken modern bir hikâye ve roman yazarı gibi dikkatli tasvirler yaptı̆̆ görülmekle beraber Harnâme'nin bir olay öyküsü olduğu söylenebilir. Zira kaynaklar da eserde anlatılan hikâyenin biyografik bir hadiseye dayandığını doğrular niteliktedir. Anlatıda kahramanlar umumiyetle insan dışı varlıklar olsa da hikâyenin asıl muhatabı insanlardır.

Mesnevide zaman kavramları çok da belirgin değildir. Hikâye kendi içerisinde genellikle kronolojik olarak ilerlese de özellikle akıllı pir eşeğin anlatıldığı bölümde zamanın kırıldığı ve geriye gidilerek anlatıya devam edildiği görülür. Pir eşekle ilgili verilen bilgilerden sonra hikâye yine kronolojik seyrinde devam eder. 
Harnâme'nin önemli yapı unsurlarından birisi de şairin hikâye içerisinde kullandığı mekânlardır. Akılsız eşeği belaya doğru götüren şeylerden biri de onun içerisinde bulunmuş olduğu mekândan memnuniyetsizliğidir. Bu memnuniyetsizlik adım adım onu trajik-komik sonuca doğru götürür. Başkahraman olan eşek, şair tarafından mekânlar arasında gezdirilirken en sonunda tarlanın sahibinin eliyle cezalandırılır. Yani hikâyenin başkahramanının başına gelenler mekân beğenmemekten ileri geldiği gibi onu kulağından ve kuyruğundan eden de tarlanın yani mekânın dönüşümüne sebep olmasidir.

Harnâme'nin şahıs kadrosu genel itibariyle insan dışı varlıklardır. Başkahraman olan cılız ve akılsız eşeğin karşısında ideal bir eşek olarak pir eşek portresi çizilir. Akılsız eşek olaylara yüzeysel bakarken akıllı eşek hikmet ehli olarak tasvir edilir. Akılsız eşeğin kendi alanının dışına çıkarak kendisini iri ve semiz olan taç (boynuz) sahibi öküzlerle kıyaslaması onu hem kulağından hem de kuyruğundan mahrum eder. Harnâme'de insan dışı varlıklarla beraber şahıs kadrosu içerisinde insanlara da yer verilmiştir. Eşeğin ve tarlanın sahipleri insan karakterler olarak mesnevide yer bulurlar. Hikâye içerisinde bunlarla ilgili ayrıntılı bilgi verilmezken bu kişiler mesnevide anahtar konumundadırlar. Zira eşeği belaya götüren en önemli sebeplerden biri eşeğin sahibinin eşeğe karşı olumsuz davranışları olmuştur. Şair, eşeğin sahibiyle ilgili ayrıntılı bilgi vermese de okuyucu bu kişinin eşeğini birçok şeyden mahrum eden zalim biri olduğunu sezer. Hikâyede tarla sahibiyle ilgili de fazla bilgi verilmezken onun eşeğin kulağını ve kuyruğunu kesen zalim biri olduğu görülür.

Harnâme'de hâkim bakış açısı söz konusu olup anlatıcı genellikle 3. şahıstır. Hikâyede ben anlatıcıya (1. şahıs) yer verildiği de görülmektedir. Başkahraman olan eşekle akıllı eşeğin diyalogları sırasında yazar anlatıcı aradan çekilir, anlatıya birinci ağızdan devam edilir. Harnâme, kısa bir hikâye olmasına rağmen anlatım teknikleri bakımından da zengindir. Şair; eserinde anlatma, tasvir, diyalog, iç monolog, özetleme, geriye dönüş gibi tekniklerden istifade etmiştir.

Şeyhî, eserinde kullandığı dil ve üslup bakımından da başarılıdır. Eser, 15. yüzyldda yazılan bir hikâye olmasına rağmen sade ve anlaşılır bir Türkçeyle kaleme alınmıştır. Mesnevide yer yer Arapça ve Farsça sözcük ve tamlamalara yer verilse de esere hâkim olan dil Türkçedir. Harmâme'nin Türkçenin başarılı bir eseri olduğu söylenebilir. Şair anlatımda da başarılıdır. Şair, eserinde merak uyandıran ögeleri birbiri ardınca sıralar. Bu, okuyucuda eserin sonunda ne olacağı fikrini oluşturur. Okuyucu hep bir sonraki adımda neler olacağını merak eder. Eserin sonundaki trajik-komik durum okuyucuda başkahramana karşı bir acıma hissi oluşturur. Hikâyenin başkahramanı, adım adım belâ bendine doğru yol alırken şair hikâyesine kattığı mizahî havayla aynı zamanda kahramanına karşı bıyık altından gülmektedir. Şairin, anlatıda sade ve anlaşılır bir dil kullanmasının yanında mesnevide edebî sanatları kullanma yönüyle de başarılı olduğu söylenebilir.

\section{Kaynakça}

Aktaş, Ş. (2005). Roman Sanatı ve Roman İncelemesine Giriş (7. Baskı). Ankara: Akçağ.

Aktaş, Ş. (2011). "Roman Olarak Hüsn ü Aşk”. Edebiyat ve Edebî Metinler Üzerine Yazılar. Ankara: Kurgan Edebiyat Yay. s. 368-382.

Alemdaroğlu, S. (2008). Fuzûlînin Leylâ ve Mecnûn Mesnevisinin Roman Tekniği Bakımından İncelenmesi. Elazığ: Firat Üniversitesi Sosyal Bilimler Enstitüsü. Yüksek Lisans Tezi.

Demirel, Ş. (1995). Heft- Peyker Metin- İnceleme. Elazı̆̆.

Demirel, Ş. (2001). "16. Yüzyıl Divan Şairlerinden Behiştî ve Heft-Peyker Mesnevisinin Tematik Açıdan İncelenmesi”. Türkiyat Araştırmaları Dergisi Selçuk Üniversitesi Türkiyat Araştırmaları Enstitüsü, S:9. 187-217. 
Ece. S. (2002). "Modern Öyküleme Teorileri Açısından Mesnevi”. A. Ü. Türkiyat Araştırmaları Enstitüsü Dergisi. Erzurum. Sayl. 20. s. 99-105.

Doğan, M. C. (2000). “Şiir ve Hikâye”. Türk Öykücülüğü Özel Sayısı. Hece. Ankara.

Faik Reşat. Eslâf (Hzl: Şemsettin Kutlu). Tercüman 1001 Temel Eser.

İsen, M. (1990). Latifi Tezkiresi, Ankara: Kültür Bakanlığı Yayınları.

İsen, M. (1994). Künhü’l-Ahbâr'ın Tezkire Kısmı. Ankara: Atatürk Kültür Merkezi Yayını.

İsen, M. (1998). Sehi Bey Tezkiresi Heşt- Behişt. Ankara: Akçağ Yayınları.

Kekeç, İ. (2017). "Türk Edebiyatında Mesnevi ve Roman İlişkisine Dair Görüşler Üzerine Bir Değerlendirme". HIKMET-Akademik Edebiyat Dergisi [Journal of Academic Literature]. Gelenek ve Postmodernizm Özel Sayısı. Yil 3. s. 186-194.

Köksal, F. (2005). “Tahkiyeli Bir Eser Olarak Taşlıcalı Yahya'nın Şâh u Gedâ Mesnevisi”. Klâsik Türk Şiiri Araştırmaları. Ankara: Akçă̆ Yayınları. s. 29-68.

Kutluk, İ. (1989). Kinalzzâde Hasan Çelebi Tezkiretü’ş-Şuarâ 1. Cilt. Ankara: TTK. Basımevi.

Kutluk, İ. (1997). Beyâni Mustafa Bin Carullah Tezkiretü’ş-Şuarâ. Ankara: TTK. Basımevi.

Mengi, M. (2012). Eski Türk Edebiyatı Tarihi. Ankara: Akçağ Yayınları.

Özdemir, M. (2010). "Harnâme’nin Tahkiye Dışındaki Bölümlerine Şekil ve Muhteva Açısından Bakış”. Uşak Üniversitesi Sosyal Bilimler Dergisi (2010) 3/1, 68-82.

Özger, M. (2004). Lâmiı̂ Çelebïnin Vâmık u Azra Mesnevisinin Modern Roman Tekniklerine Göre İncelenmesi. Malatya: İnönü Üniversitesi Sosyal Bilimler Enstitüsü. Yüksek Lisans Tezi.

Saraç, A. Y. (2000). “Divan Edebiyatı’nda Hikâye”. Türk Öykücülüğü Özel Sayısı. Hece Ankara.

Şentürk, A. A. ve Kartal, A. (2009). Eski Türk Edebiyatı Tarihi. İstanbul: Dergâh

Tekin, M. (2001). Roman Sanatı. İstanbul: Ötüken Yayınları.

Timurtaş, F. K. (1971). Şeyhî’nin Harnâme’si. İstanbul: Edebiyat Fakültesi Basımevi.

Ülger, S. (2003). Leylâ ve Mecnun'da Hikâye Tekniği. İstanbul: İstanbul Üniversitesi Sosyal Bilimler Enstitüsü. Doktora Tezi.

Yılmaz, K. (2016). "Klâsik Türk Edebiyatında Mizah: Harnâme-Şikâyetnâme Örneği" HíKMETAkademik Edebiyat Dergisi [Journal of Academic Literature]. Prof. Dr. Mine MENGi Özel Sayısı. Yıl 2. Sayı 5. s. 198-203. 